\author{
JURNAL EINSTEIN \\ Jurnal Hasil Penelitian Bindang Fisika \\ Available online http://jurnal.unimed.ac.id/2012/index.php/einsten \\ e-issn: $2407-747 x$, p-issn $2338-1981$
}

\title{
PENDETEKSIAN RESISTIVITAS LAPISAN PERMUKAAN BAWAH TANAH CANDI SIPAMUTUNG DENGAN METODE GEOLISTRIK DIDESA SIPARAU KECAMTAN BARUMUN TENGAH KABUPATEN PADANG LAWAS
}

\author{
Meilidia Mangunsong, Karya Sinulingga dan Rahmatsyah \\ Jurusan Fisika, Fakultas Matematika dan Ilmu Pengetahuan Alam, Universitas Negeri Medan, \\ Indonesia \\ meisimangunsong114@gmail.com \\ Diterima September 2018; Disetujui Oktober 2018; Dipublikasikan November 2018
}

\begin{abstract}
ABSTRAK
Telah dilakukan penelitian geolistrik untuk menentukan batuan bawah permukaan Candi Sipamutung di daerah siparau Kecamatan Barumun Tengah Kabupaten Padang Lawas. Penelitian ini bertujuan untuk mengetahui struktur perlapisan secara horizontal dan vertikal di daerah lokasi candi Sipamutung berdasarkan nilai resistivitasnya. Penentuan jenis batuan di bawah permukaan candi dilakukan dengan menggunakan alat geolistrik ARES (Automatic Resistivity System) D4.vv4, SN : 0609134 dengan metode Schlumberger sebanyak 3 lintasan dan panjang lintasan 75 meter dengan jarak antar elektroda 5 meter. Nilai resistivitas bawah permukaan diolah menggunakan software Res2Dinv didapatkan penampang dua dimensi. Penentuan titik penelitian menggunakan GPS (Global Position System). Hasil penelitian geolistrik menunjukkan bahwa nilai resistivitas terendah dan tertinggi pada lokasi penelitian yaitu $3 \Omega \mathrm{m}$ dan $1386 \Omega \mathrm{m}$ yang didominasi batu aluvium dan andesit. Jenis batuan yang terdapat di bawah lokasi penelitian berupa lapisan air tanah dengan resistivitas $3 \Omega \mathrm{m}-7,21 \Omega \mathrm{m}$, lempung dengan resistivitas antara $8 \Omega \mathrm{m}-120 \Omega \mathrm{m}$, nilai resistivitas $240 \Omega \mathrm{m}-577 \Omega \mathrm{m}$ sebagai aluvium, dan resistivitas $743 \Omega \mathrm{m}$ $1400 \Omega \mathrm{m}$ merupakan batuan andesit.
\end{abstract}

Kata Kunci : Geolistrik, Candi Sipamutung, Res2dinv

\section{PENDAHULUAN}

Candi Sipamutung (Biaro Sipamutung) adalah salah satu candi bercorak Buddha peninggalan Kerajaan Pannai di Kompleks Percandian Padanglawas. Secara administratif, candi ini terletak di Desa Siparau Kecamatan Barumun Tengah, Kabupaten Padanglawas, Provinsi Sumatera Utara. Kabupaten padang Lawas terletak pada koordinat $1^{\circ} 19^{\prime} 17^{\prime \prime}$ 1²9'25" Lintang Utara, 99³5'07" - 9946'23" Bujur Timur (BPS Paluta, 2016).

Candi Sipamutung berada pada persimpangan sungai batang pane dan sungai barumun, berdiri pada areal dataran tinggi dengan lingkungan alam yang tampak gersang. Dalam kompleks candi terdapat lima buah bangunan-bangunan berupa gundukan tanah yang berdekatan dengan candi induk. Pada kompleks candi terdapat pula temuan lepas berupa patung/arca dan lapik. Kanwi Depdikbut frovinsi sumatera utara, bidang muskala bekerja sama dengan Pemda TK.1 sumatera utara telah melakukan pemugaran pada kompleks candi ini (Teuku Hanif, 2010).

Berdasarkan peta geologi, di daerah Siparau tepatnya menunjukkan permukaan bawah Candi Sipamutung terdiri dari Aluvium (lempung sungai dan pantai, lanau, pasir dan 
kerikil, termasuk endapan kipas longsoran tanah dan terban, gambut), Formasi Petani (batu pasir berkarbon terbioturbasikan, batu lanau dan serpih, batu pasir) (Dinas Pertambangan dan Energi, 2017).

Untuk mengidentifikasi jenis batuan dibawah permukaan candi maka diperlukan suatu metode pemetaan bawah permukaan tanah agar penggalian dapat dilakukan tanpa menimbulkan kerusakan terutama terhadap situs yang masih terkubur. Aplikasi metode geolistrik tahanan jenis digunakan sebagai solusi untuk menyelidiki keberadaan batuan candi yang masih terkubur di sekitar lokasi penemuan pondasi batuan tersebut (Broto dan Rohima, 2008).

Metode geolistrik merupakan metode Geofisika yang mempelajari sifat aliran listrik di dalam bumi dan cara untuk mendeteksi aliran di permukaan bumi. Hal ini meliputi pengukuran potensial dan pengukuran arus yang terjadi baik secara alamiah maupun akibat injeksi arus kedalam bumi. Oleh karena itu metode geolistrik mempunyai banyak macam, salah satunya adalah metode geolistrik tahanan jenis (Rochman dkk, 2017).

Metode geolistrik dimaksudkan untuk mengetahui susunan, kedalaman, dan penyebaran lapisan bawah permukaan dari titik pendugaan berdasarkan harga tahanan jenis yang diperoleh. Penggunaan metode geolistrik ini diharapkan dapat memberikan informasi tentang inhomogeneties bawah permukaan.

Metode geolistrik resistivitas bekerja karena pengukuran beda potensial pada titik-titik di permukaan bumi yang diproduksi dengan langsung mengalirkan arus ke bawah permukaan, hal ini bermanfaat untuk menentukan distribusi resistivitas di bawah permukaan dan kemudian digunakan untuk interpretasi material material yang potensial, kita perlu meninjau ulang secara singkat konsep kelistrikan (Burger,1992).

\section{METODE PENLITIAN}

Penelitian dilaksanan di desa Siparau Kecamatan Barumun Tengah Kabupaten Padang Lawas dengan menggunakan alat Geolistrik ARES. Penentuan data grid daerah survey menggunakan GPS ( Global Position System) map dan pengukuran menggunakan Geolistrik dilakukan dengan konfigurasi Schlumberger.
Data yang diperoleh dari hasil penelitian diolah menggunakan software Res2dinv sehingga diperoleh model penampang dua dimensi sepanjang lintasan. Software Res2dinv merupakan program yang dibuat untuk menghitung serta menggambarkan harga resistivitas dari hasil perhitungan dilapangan. Dengan memasukkan data yang ada yaitu nilai arus dan beda potensial, harga resistivitasnya dapat terlihat langsung dari perbedaan warna pada setiap lapisan.

Dalam penelitian ini, pengukuran data geolistrik resistivitas konfigurasi Schlumberger dilakukan sebanyak tiga lintasan pengukuran dengan panjang lintasan 75 meter dan jarak antar elektroda 5 meter sebanyak 16 elektroda.

Hasil inversi dari ketiga lintasan dianalisis dan dibandingkan dengan menggunakan harga resistivitas tanah dan batuan menurut Santoso (2002). Interpretasi data dari batuan tersebut berbeda setiap lintasan karena nilai resistivitas yang berbeda.

\section{Prosedur Penelitian}

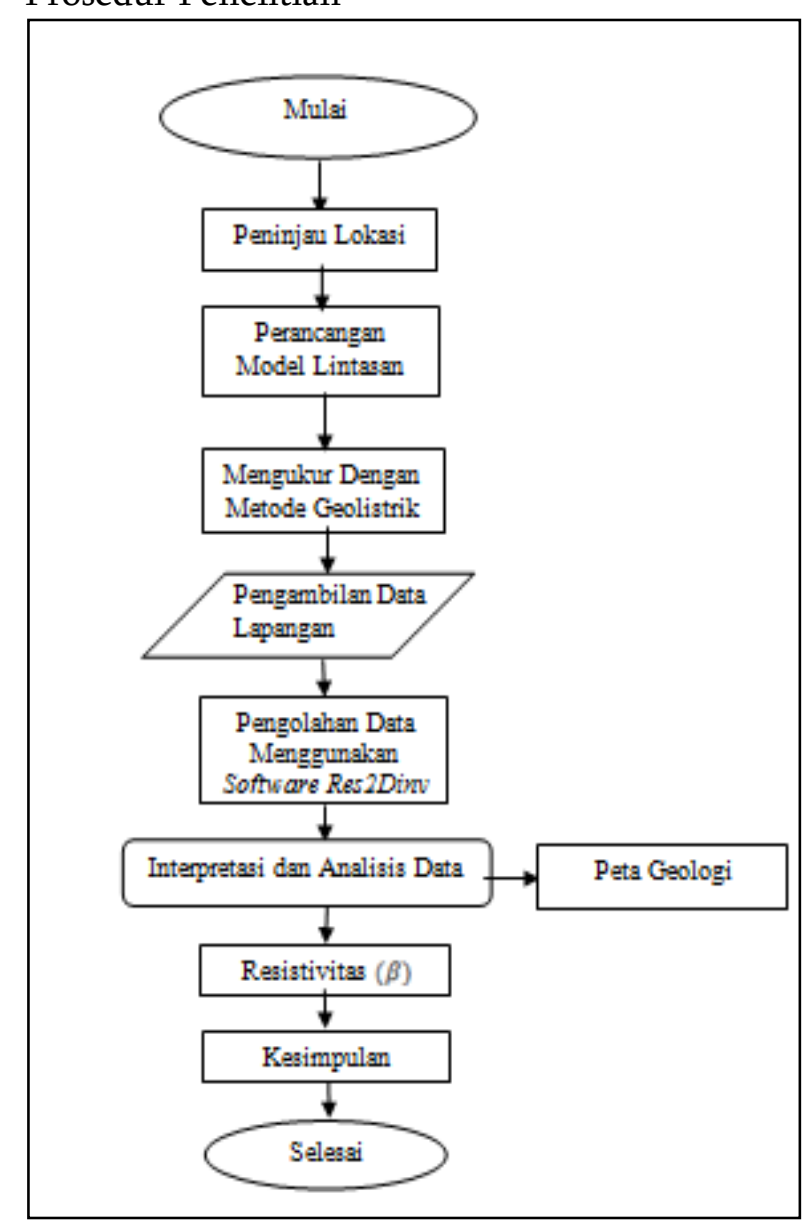

Gambar 1. Diagram alir penelitian 
Langkah-langkah yang dilakukan untuk pengambilan data geolistrik berdasarkan Gambar 1 adalah sebagai berikut:

1. Meninjau/survei lokasi serta pengambilan gambar yang akan dijadikan sebagai daerah penelitian.

2. Menentukan lintasan untuk pengambilan data dan menentukan posisi daerah dengan GPS.

3. Melakukan pengambilan data menggunakan metode geolistrik ARES D4.vv4, SN: 0609134 konfigurasi Schlumberger.

4. Mengolah data yang diperoleh dari tabel geolistrik menggunakan Software Res2dinv sehingga diperoleh mode penampang dua dimensi sepanjang lintasan.

5. Proses akuisi data lapangan dengan Software surfer.

6. Membedakan nilai resistivitas berdasarkan warna untuk menganalisis jenis batuan.

\section{HASIL DAN PEMBAHASAN}

Hasil pengamatan data geologi berdasarkan Gambar 2 dari lokasi penelitian menunjukkan Desa Siparau Kecamatan Barumun Tengah tepatnya permukaan bawah Candi Sipamutung terdiri dari Aluvium (lempung sungai dan pantai, lanau, pasir dan kerikil, termasuk endapan kipas longsoran tanah dan terban, gambut), Formasi Petani (batu pasir berkarbon terbioturbasikan, batu lanau dan serpih, batu pasir).

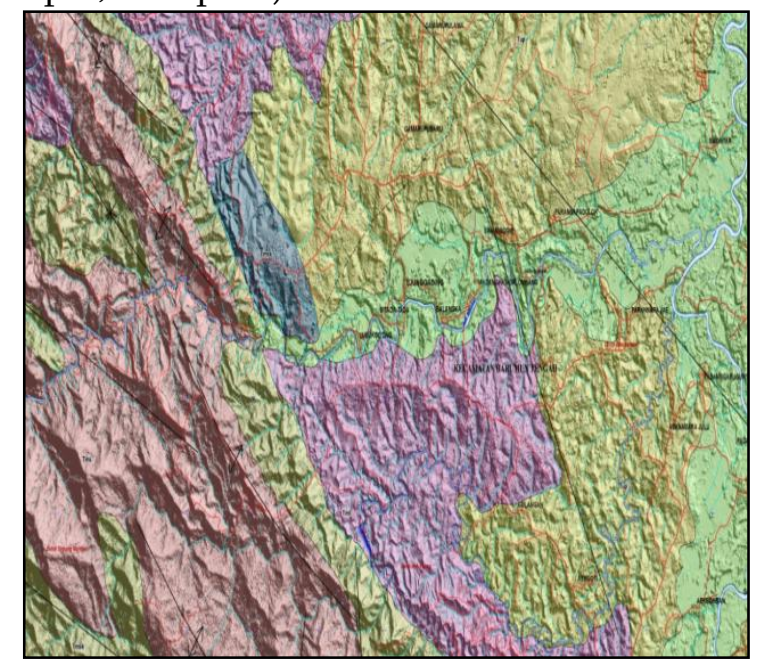

Gambar 2. Lokasi Penelitian (Dinas

Pertambangan dan Energi, 2017)
Daerah yang akan diteliti memiliki ketinggiannya rata-rata sekitar 67 meter dpl. Sungai Batang Pane berada dekat dengan lokasi penelitian dan lokasi penelitian dikelilingi dengan pohon kelapa sawit. Pada lokasi dilakukan penelitian dengan tiga lintasan. Gambar 3. menunjukkan bentuk ketiga lintasan.

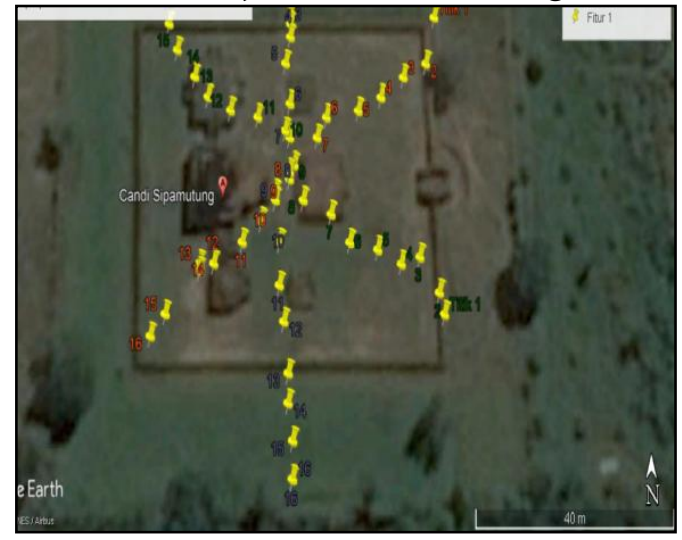

Gambar 3. Bentuk Lintasan Geolistrik (Google Earth, 2018)

Hasil penelitian pada lintasan pertama dapat dilihat pada Gambar 4.

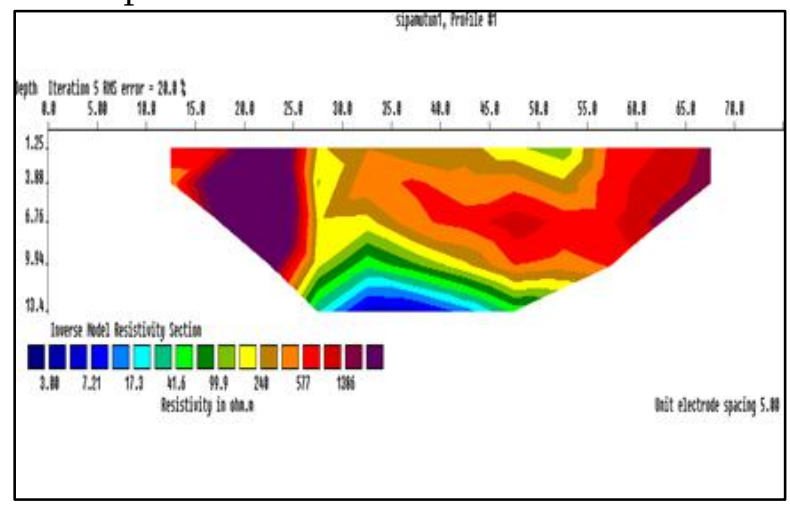

Gambar 4. Peta pseudosection lintasan 1

Pada lintasan pertama didominasi oleh Nilai resistivitas berkisar antara $3 \Omega \mathrm{m}-7,21 \Omega \mathrm{m}$, ditafsirkan sebagai lapisan air tanah, di kedalaman 12,6 meter, dengan warna biru tua dan biru muda. Nilai resistivitas berkisar antara 8 $\Omega \mathrm{m}-120 \Omega \mathrm{m}$, ditafsirkan sebagai lempung, di kedalaman 10,5- 12,6 meter, dengan warna biru muda dan warna coklat muda. Nilai resistivitas berkisar antara $240 \Omega \mathrm{m}-577 \Omega \mathrm{m}$, ditafsirkan sebagai aluvium , di kedalaman 1,25 - 9,94 meter, dengan warnah coklat tua dan merah. Nilai resistivitas berkisar antara $743 \Omega \mathrm{m}-1400 \Omega \mathrm{m}$, ditafsirkan sebagai batuan andesit, di kedalaman 1.25 - 9.94 meter, dengan warna merah dan 
ungu. Hasil penelitian pada lintasan kedua dapat dilihat pada Gambar 5 berikut:

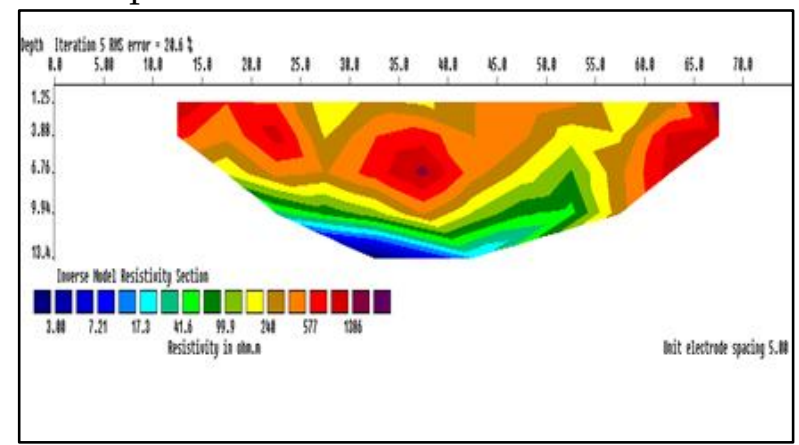

Gambar 5. Peta pseudosectionlintasan 2

Pada lintasan kedua yang didominasi oleh Nilai resistivitas berkisar antara 3,00 $\Omega \mathrm{m}-$ $17,3 \Omega \mathrm{m}$, ditafsirkan sebagai lapisan air tanah, di kedalaman 10 - 13,4 meter, dengan warna biru tua dan biru muda. Nilai resistivitas berkisar antara 41,6 $\Omega \mathrm{m}-240 \Omega \mathrm{m}$, ditafsirkan sebagai lempung dengan warna biru mudah dan warna coklat mudah, di kedalaman 1,25 - 9,94 meter, dengan warna hijau dan coklat muda. Nilai resistivitas berkisar antara $120 \Omega \mathrm{m}-743 \Omega \mathrm{m}$, ditafsirkan sebagai lapisan aluvium, di kedalaman 1,25 - 6,76 meter, dengan warna coklat dan merah. Hasil penelitian pada lintasan ketiga dapat dilihat pada Gambar 6 berikut:

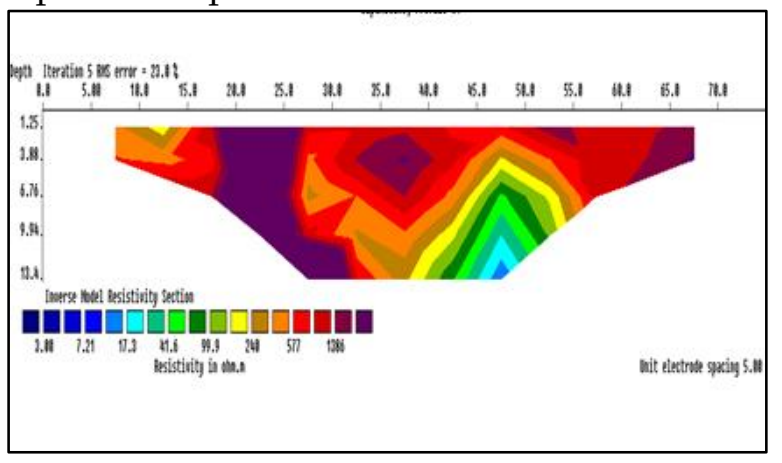

Gambar 6. Peta pseudosectionlintasan 3

Pada lintasan ketiga yang didominasi oleh Nilai resistivitas berkisar antara 10,5 $\Omega \mathrm{m}$ $60 \Omega \mathrm{m}$, ditafsirkan sebagai lempung, dikedalaman 9,94 - 13,4 meter, dengan warna biru dan biru muda. Nilai resistivitas berkisar antara 99,9 $\Omega \mathrm{m}-240 \Omega \mathrm{m}$, ditafsirkan sebagai kerikil, di kedalaman 1,25 - 9,94 meter, dengan warna hijau dan coklat. Nilai resistivitas $365 \Omega \mathrm{m}$ - $577 \Omega \mathrm{m}$, ditafsirkan sebagai aluvium, dikedalaman 1,25 - 13,4 meter, dengan warna kuning dan orange. Nilai resistivitas $743-1400$ $\Omega \mathrm{m}$, ditafsirkan sebagai batuan andesit, di kedalaman 1,25 - 13,4 meter, dengan warna merah dan ungu.

Nilai resistifitas secara vertikal dapat dilihat pada gambar 7. dengan pengelompokan kedalam 1,25 m, 5m, 10m, dan 12,5m. Sebaran nilai resistivitas pada gambar 4.5 adalah nilainilai yang diambil dari penampang bawah permukaan bumi hasil olahan program software Res2dinv berupa resistivitas model sebenarnya untuk seluruh lintasan.

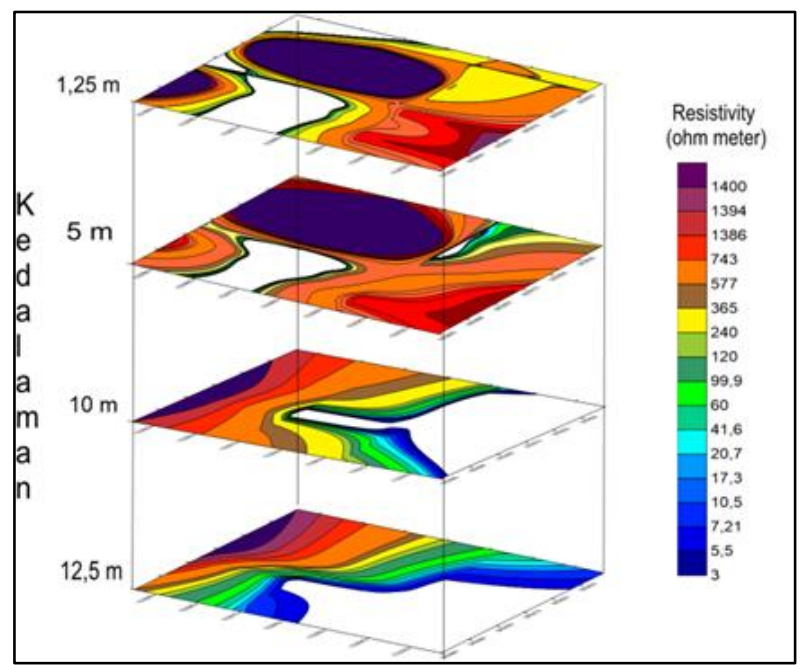

Gambar7. Resistivitas Penampang Vertikal

Perlapisan bawah permukaan Candi Sipamutung secara vertikal hasil pengolahan data menggunakan Software Surfer 11 dapat dilihat pada gambar 4.5, yang menunjukkan sebaran lapisan pada tiap perlapisan. Pada kedalaman 1,25 $\mathrm{m}$ didominasi oleh batuan kerikil, aluvium, dan andesit dengan nilai resisitivitas $99,9 \Omega \mathrm{m}-1400$ $\Omega \mathrm{m}$, pada kedalaman $5 \mathrm{~m}$ didominasi oleh kerikil, aluvium, dan andesit dengan nilai resistivitas 99,9 $\Omega \mathrm{m}-1400 \Omega \mathrm{m}$, Pada kedalaman $10 \mathrm{~m}$ didominasi oleh lempung, aluvium dan andesit dengan nilai resistivitas $10,5 \Omega \mathrm{m}-1400 \Omega \mathrm{m}$, pada kedalaman 12,5 m didominisi oleh lempung, aluvium, dan andesit dengan nilai resistivitas $10,5 \Omega \mathrm{m}-1400$ $\Omega \mathrm{m}$.

Penampang secara horizontal dapat dilihat pada gambar 8 . dengan pengelompokan 20 $\mathrm{m}, 30 \mathrm{~m}, 40 \mathrm{~m}, 50 \mathrm{~m}$, dan $60 \mathrm{~m}$. 


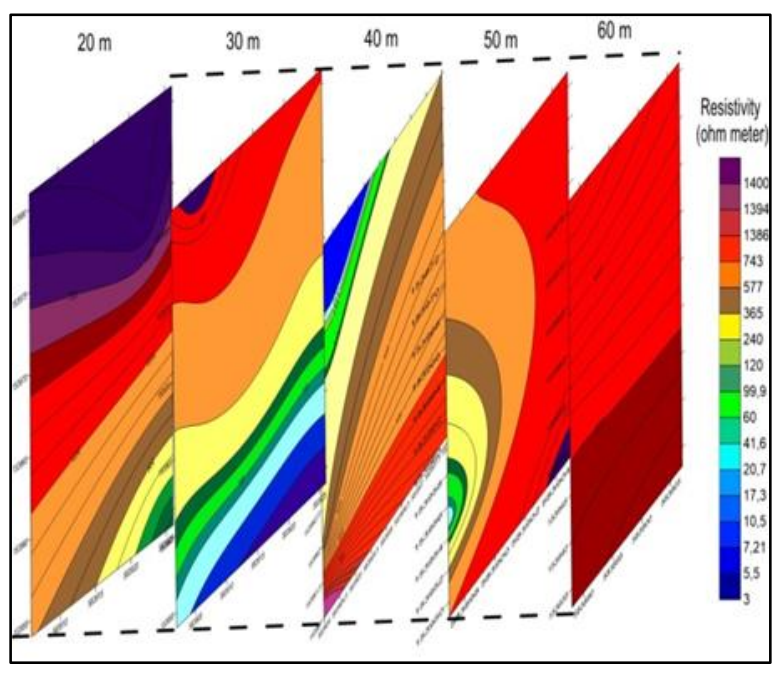

Gambar 8. Resistivitas Penampang Horizontal

Penampang horizontal bawah permukaan candi Sipamutung dibagi kedalaman 5 sayatan dengan nilai resistivitas yang berkisar 3 $\Omega \mathrm{m}$ sampai $1400 \Omega \mathrm{m}$, dimana setiap sayatan mempunyai citra warna yang berbeda menunjukkan jenis batuan yang berbeda.

Jarak 20 meter didominasi dengan andesit dengan nilai resistivitas $120 \Omega \mathrm{m}-1400$ $\Omega \mathrm{m}$. Jarak 30 meter dan 40 meter didominasi oleh lempung, kerikil dan aluvium dengan nilai resistivitas $3 \Omega \mathrm{m}-743 \Omega \mathrm{m}$. Jarak 50 meter didominasi lempung, aluvium, dan andesit dengan nilai $3 \Omega \mathrm{m}$ dan $20,7 \Omega \mathrm{m}-743 \Omega \mathrm{m}$. Jarak 60 meter didominasi oleh andesit dengan nilai $743 \Omega \mathrm{m}-1386 \Omega \mathrm{m}$.

\section{KESIMPULAN DAN SARAN}

Dari hasil pengolahan, analisis dan interpretasi data pada penelitian dapat disimpulkan bahwa :

1. Hasil struktur perlapisan secara horizontal dan vertikal di daerah lokasi candi Sipamutung berdasarkan nilai resistivitasnya adalah pada kedalam 1,25 $\mathrm{m}$ didominasi oleh batuan kerikil, aluvium, dan andesit dengan nilai resisitivitas $99,9 \Omega \mathrm{m}-1400 \Omega \mathrm{m}$, pada kedalaman $5 \mathrm{~m}$ didominasi oleh kerikil, aluvium, dan andesit dengan nilai resistivitas 99,9 $\Omega \mathrm{m}-1400 \Omega \mathrm{m}$, Pada kedalaman $10 \mathrm{~m}$ didominasi oleh lempung, aluvium dan andesit dengan nilai resistivitas $10,5 \Omega \mathrm{m}-1400 \Omega \mathrm{m}$, pada kedalaman 12,5 m didominisi oleh lempung, aluvium, dan andesit dengan nilai resistivitas $10,5 \Omega \mathrm{m}-1400 \Omega \mathrm{m}$, dan pada jarak 20 meter didominasi dengan andesit dengan nilai resistivitas $120 \Omega \mathrm{m}$ $1400 \Omega \mathrm{m}$. Jarak 30 meter dan 40 meter didominasi oleh lempung, kerikil dan aluvium dengan nilai resistivitas 3Dm $743 \Omega \mathrm{m}$. Jarak 50 meter didominasi lempung, aluvium, dan andesit dengan nilai $3 \Omega \mathrm{m}$ dan $20,7 \Omega \mathrm{m}-743 \Omega \mathrm{m}$. Jarak 60 meter didominasi oleh andesit dengan nilai $743 \Omega \mathrm{m}-1386 \Omega \mathrm{m}$.

2. Hasil situs Candi yang terbenam dibawah permukaan Candi adalah terdapat batuan andesit yang diduga sebagai pembentuk candi dengan nilai resistivitas $743 \Omega \mathrm{m}$ $1400 \Omega \mathrm{m}$.

\section{DAFTAR PUSTAKA}

Badan Pusat Statistika (BPS)., (2016), KabupatenPadang Lawas Dalam Angka 2016, BPS Kabupaten Padang Lawas Utara.

Broto, S. dan Rohima S.A., (2008), Pengolahan Data Metode Geolistrik Dengan Metode Schlumberger, Jurnal Teknik, 29:120-128

Burger, Henry Robert., (1992), Eksploration Geophysics of the Shallow Subsurface, New Jersey: Prentice Hall.

Dinas Pertambangan dan Energi, (2017), Bandung

Hanif, Teuku., (2010), Data Penetapan Benda Cagar Budaya/Situs, Balai Pelestarian Peninggalan Purbakala Aceh, Sumatera Utara

Hendrajaya, L., Arif, I., (1990), Geolistrik Tahanan Jenis, Laboratorium Fisika Bumi, Fisika FMIPA, ITB.

Jayanti, S. D., Darsono., dan Budi Legowo., (2012), Identifikasi Situs Candi Bukit Carang, Karanganyar Menggunakan Metode Geolistrik Tahanan Jenis Konfigurasi Dipol-Dipol, Vol. 2 No. 1, Universitas Sebelas Maret, Surakarta.

Rochmana, J.P.G.N., Widodo, A., Bahri, A.S., Syaifuddin, F., dan Lestari, W., (2017), Aplikasi Metode Geolistrik Tahanan Jenis Untuk Mengetahui Bawah Permukaan di Kompleks Candi 
Meilidia Mangunsong, Karya Sinulingga dan Rahmatsyah, Pendeteksian Resistivitas Lapisan Permukaan Bawah Tanah

Candi Sipamutung Dengan Metode Geolistrik Didesa Siparau Kecamtan Barumun Tengah Kabupaten Padang Lawas

Belahan (Candi Gapura), Jurnal

Geosaintek,Vol. 03 No. 01: 93-98.

Susetyo, S., (2010), "Stambha-stambha dari Padang Lawas", Sumatera Utara, Pentas Ilmu di Ranah Budaya, Pustaka Larasan, Denpasar-Bali.

Santoso, D., (2002), Pengantar Teknik Geofisika, Departemen Teknik Geofisika ITB, Bandung. 